\title{
Implementation Opportunities of Geothermal Energy Systems in the Peripheries along the Border of Hungary and Romania
}

\author{
Balázs KulcsárA \\ Received: March 13, 2015 | Revised: August 12, 2015 | Accepted: September 1, 2015
}

\begin{abstract}
With the utilization of the available potentials and technologies, geothermal energy may contribute to the reduction of the quantities of the emitted contaminants and greenhouse gases, as well as the development of peripheral regions. Towards this end, such governmental measures are needed that set up a favourable regulatory environment, and put the financial funds for the support of implementation in place so that geothermal energy resources could complement the currently used, conventional energy carriers, and more efficient settlement development could be achieved. In this context, the University of Debrecen and the University of Oradea have conducted joint studies with the purpose of making a realistic assessment of geothermal energy resources in the region of Săcueni-Létavértes and examining the options of long-term utilization. The research has been multidisciplinary, and thus embraced the field of geography, geodetics, well drilling, automation, mechanical engineering and tourism. The principal goal has been the utilization of geothermal energy with the largest possible efficiency in the area of Săcueni and Létavértes.
\end{abstract}

Key words: geothermal energy, settlement management, settlement development, regional development, Létavértes, Săcueni

\section{Introduction}

From the broad-scaling studies, this article intends to highlight the importance of geothermal energy in settlement development in view of the region of Létaverrtes and Săcueni, on the basis of the available geothermal potentials. Beyond the general description of the geologic, hydrogeologic properties, the geothermal endowments of the microregion of LétavértesSăcueni are also specified alongside the parameters of the thermal wells that have already been established, the current situation of thermal water utilization.

This analysis has examined who those potential consumers in the two settlements could be, whose demands for heat and water could be efficiently satisfied by a geothermal system operated in the two settlements. In theory, with an appropriate volume of thermal water in place, what a local district or range Létavértes and Săcueni could supply, to what a distance thermal water could be transported, and what types of users could be served with thermal water. The analysis has relied on the empirical data of the system operated by Aquaplus Kft. in Kistelek as concerning transportability, as well as the Lindal diagram, which designates the areas of use for thermal waters of varied temperatures. In the analysis, I have further examined the distances of the surrounding settlements from Săcueni and Létavértes, and assumed that the center of the potential geothermal systems can be these two settlements. In the light of the distance values, the empirical data of the transportability of the thermal water and the values of the Lindal diagram, such an area can be designated where thermal waters of varied temperatures can be utilized.

Below it will be explained and confirmed that thermal water in the region could be optimally used for sanitary hot water, district heating, swimming pool

A University of Debrecen Faculty of Engineering, H-4028 Debrecen, Ótemető u. 2-4; kulcsarb@eng.unideb.hu 
and bathing services, i.e. the purposes of communal heat supply and tourism. In any multiphase utilization, it is agriculture that can be the final user. For this reason, I have considered it to be necessary to examine the positive aspects of the utilization of thermal water in the field of the maintenance of public institutions, economic development and tourism.

\section{Geothermal endowments}

\section{Geological bases of the region}

The examined settlements are situated on the eastern edge of the Great Plain, in an area called Érmellék between the regions of Nyírség and Szilágyság. The region encompassing Létavértes and Săcueni located 17 $\mathrm{km}$ from each other lies over a deep subgrade depression (Gribovszki, Szeidovitz, 2002). This area wedged between the Flysch belt and the Békési Depression has been well explored for geothermal findings in the past decades, its thermal water production has been made known by the hydrocarbon exploratory drillings carried out in the surroundings, as well as the regional geophysical research results, and thus the area seems to be promising in view of geothermal energy production.

A consequence of the structural development of the area is that the subgrade of the Pannonian Basin is only $20-25 \mathrm{~km}$ thick, i.e. it is quite thin in comparison to the average. Such thinning of the crust was created by deep circulations within the mantle (Molnár, 1984). In this region, the geothermal gradient is $4.5^{\circ} \mathrm{C} / 100 \mathrm{~m}$, which brings about $35-40^{\circ} \mathrm{C}$ temperature at a depth of 500 meters, $55-60^{\circ} \mathrm{C}$ at 1000 meters, and up to $100-$ $130^{\circ} \mathrm{C}$ at 2000 meters (Mádlné Szőnyi, 2008). From the decomposed and sedimentary rocks making up even thousands of meters of thickness under the surface - comprising sand, sandstone, siltstone, clay in the Great Plain -, thermal water featuring temperatures over $30^{\circ} \mathrm{C}$ can be explored in most of the basin (Liebe, 2001). Some of the water bodies found there are fossil waters, as well as reservoirs supplied from the bordering mountains. The highest temperature that can potentially be exploited from the Upper Pannonian sediment does not reach $100^{\circ} \mathrm{C}$ anywhere, meaning that this area belongs to low-enthalpy systems. The water permeability of the Upper Pannonian sand and sandstone (Great Plain Aquifer) is $10^{-5} \mathrm{~m} / \mathrm{s}$, and therefore up to $10-100 \mathrm{cc} \mathrm{m} / \mathrm{h}$ water yield can be produced from the wells. The sediment under the Great Plain Aquifer is made up of water-trapping siltstone and clay. In and under the water traps, overpressure prevails everywhere at varied locations throughout the area. In the regions lying closer to the examination areas, such as in the surroundings of Biharkeresztes, however, 2-6
MPa overpressure can be found at a depth of 1200 meters, and then from 2200 meters the extent of the overpressure exceeds $10 \mathrm{MPa}$. It is quite likely that the layers under the examined area feature similarly high hydrostatic pressure as the Biharkeresztes region. The overpressure reservoirs are closed, and therefore their exploitation potentials depend on the regional storage factors. As a consequence the reservoir cannot be utilized without reinjection at all (Tóth, 2006). In view of the establishment of artificial geothermal systems (EGS), there are several promising sites in the Pannonian Basin. The best parameters can be found in the southern and southeastern part of the Great Plain, in particular on the edges of the deep basins and the elevated base mountainous areas in between the basins, including the region of Derecske lying in the vicinity of the studied area (Dövényi, et al., 2005).

\section{Geothermal endowments of Săcueni}

The data that is available in connection with the thermal wells having been established since the 1980 s in Săcueni are encouraging in view of the more effective exploitation of the potentials. In these wells, the temperature of thermal water is in the range of 50$80^{\circ} \mathrm{C}$, comes to the surface at a pressure of $0.5-0.8$ $\mathrm{MPa}$, while its chemical composition - $\mathrm{HCO}_{3}, \mathrm{Cl}, \mathrm{Na}$, $\mathrm{I}, \mathrm{Br}-$ makes it suitable for therapeutic purposes and use in bathing facilities in addition to geothermal energy utilization. Its phenol content varies between 1.8 and $2.55 \mathrm{mg}$, which should be handled as a source of environmental risk in case it is discharged into surface recipients (Erdei, et al., 2010). The thermal water springing up on the surface suggests a closed, fossil reservoir, which would call for reinjection (Bálint, Szongoth, 2010).

In the course of the exploratory drilling works commenced in 1968, the crude oil probes no. 4058, 4055, 4056 and 4031 revealed gasoline in two collecting layers at a depth of 1700-1800 meters in the Lower Pannonian layers. The petroleum fraction sources soon became depleted, and the subsequent drilling operations created only wells of weak pressure, and therefore the exploitation was discontinued in 1995.

Since 1980, it has been drilling no. 4058 that has found thermal water at a depth of 1226-1456 meters, in the Upper Pannonian layers, with $11.5 \mathrm{l} / \mathrm{sec}$ yield, at a temperature of $84^{\circ} \mathrm{C}$. At the same depth, probe no. 4055 also brought up $81^{\circ} \mathrm{C}$ water at a $28 \mathrm{l} / \mathrm{sec}$ rate. In addition to the foregoing, 10 more drilling sites have produced thermal water with drilling no. 4057,4076 and 1704 serving water of $86-92^{\circ} \mathrm{C}$. These well capacities have never been fully employed. Nowadays, the water is used for the heating and sanitary hot water supply of the Thermal Baths, Kinder Factory, Mayor's Office, Petöfi Sándor Lyceum of Theoretical Studies, 
Table 1. Figures of thermal wells in Săcueni region (Ciucanu, 2010).

\begin{tabular}{|c|c|c|c|c|}
\hline Registration Number & Temperature $\left({ }^{\circ} \mathrm{C}\right)$ & Base Depth $(\mathrm{m})$ & Discharge $(\mathrm{l} / \mathrm{s})$ & Status \\
\hline 752 & 76 & 1456 & 3.0 & Standby \\
\hline 4055 & 81 & 1800 & 28 & Standby \\
\hline 4057 & 92 & & 11.5 & Standby \\
\hline 4058 & 84 & 1456 & 11.5 & In use \\
\hline 4076 & 85 & 1691 & 7.5 & Preservation \\
\hline 4691 & 81 & 1447 & 10.0 & Preservation \\
\hline 4692 & 60 & 1364 & & Preservation \\
\hline 4694 & & 1436 & & Preservation \\
\hline 4696 & & 1560 & & In use \\
\hline 4697 & 83 & 1596 & 13.0 & Standby \\
\hline 4696 & 84 & 1680 & 25 & Standby \\
\hline
\end{tabular}

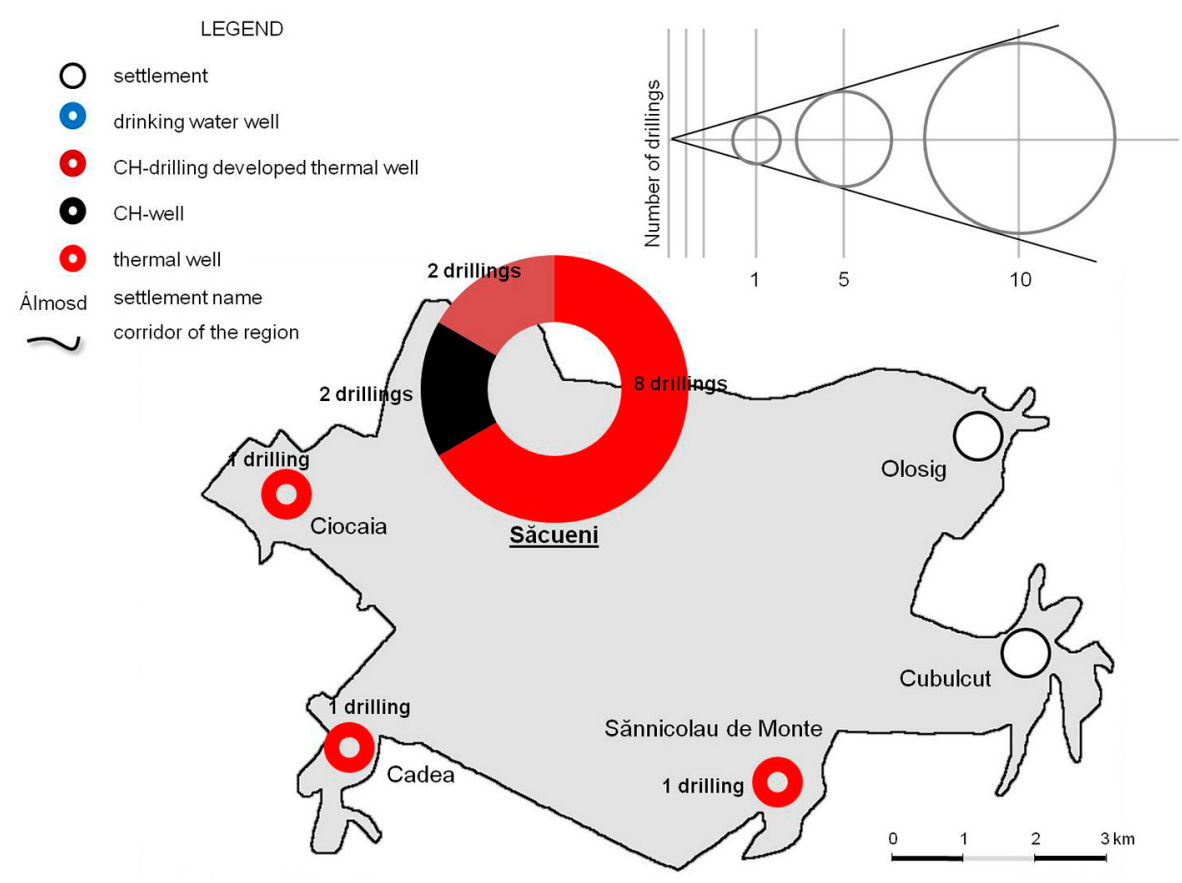

Figure 1. Thermal wells and hydrocarbon drillings in the area of the Săcueni Territorial Unit of Public Administration (TUPA)

(edited by the author based on data Popescu, 1981, Ciucanu, 2010)

Catholic Church Parish, sports hall, some apartments and the recently erected ANL blocks of flats, while further plans are under preparation for future utilization (Székelyhíd (Săcueni) Város Fejlesztési Stratégiája, 2010).

The results of the most recent drillings no. 4696 and 4497 are promising, as their water rates are $251 / \mathrm{sec}$ and $17 \mathrm{l} / \mathrm{sec}$, respectively, and they serve $84^{\circ} \mathrm{C}$ water (Table 1; Figure 1 (Popescu, 1981).

\section{Geothermal endowments of Létavértes}

In the surroundings of Létavértes, there are no operating thermal wells, and no drillings are known to have such characteristics. In spite of its geologic- hydrogeologic endowments considered to be favourable, microregion of Derecske-Létavértes does not have any facility of such utilization. The area of the microregion accommodates only low-temperature drinking water wells, as well as the exploratory drillings of Hungari- 


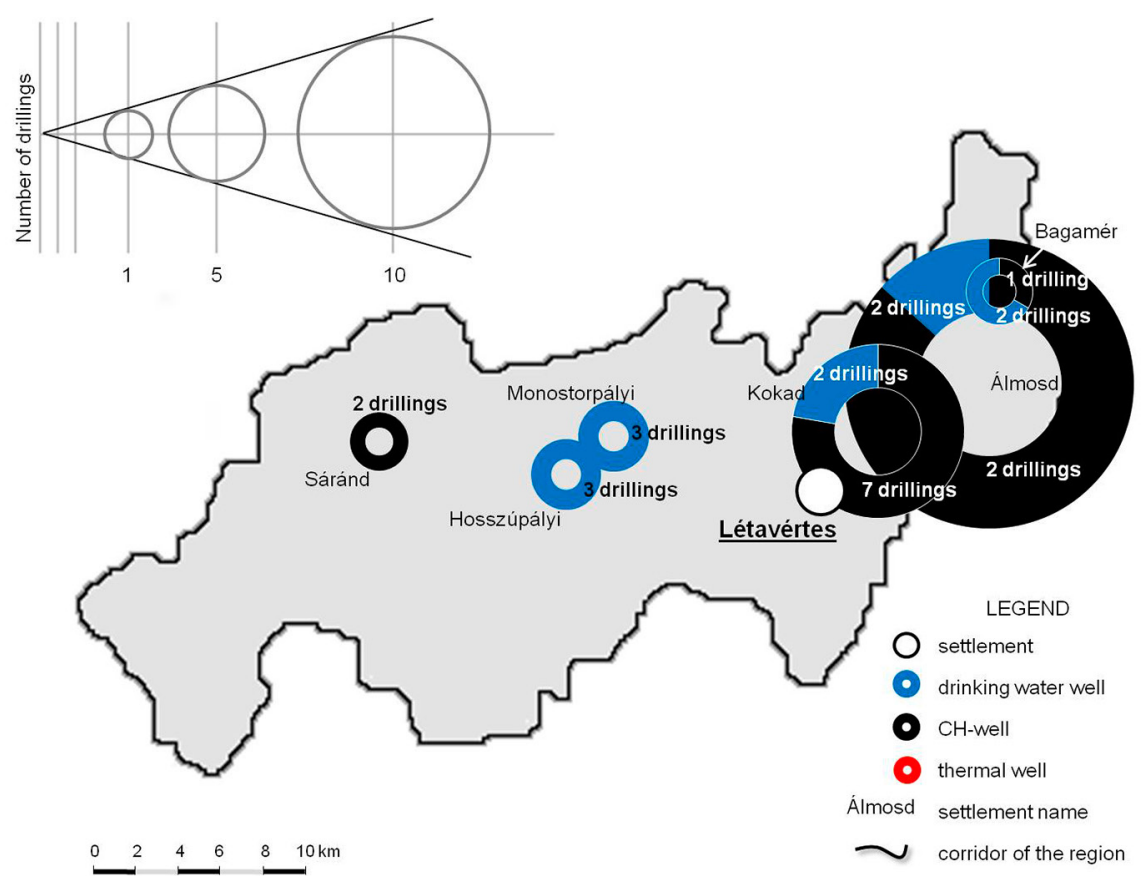

Figure 2. Drinking water wells and hydrocarbon exploratory drillings in the area of Derecske-Létavértes region (edited by the author based on data Bohn, Marczel, 1988)

an Oil and Gas Public Limited Company (MOL) made in the recent decades in search of hydrocarbons (Figure 2). However, thermal water has been found during the test drillings made in the area of Létavertes (and its surroundings) (Dövényi et al., 2005). The $72-78^{\circ} \mathrm{C}$ water originates from the same layer as the water of Hajdúszoboszló and Debrecen, and therefore its quality is likely to be similar. On the other hand, in the areas of the microregions that are adjacent to DerecskeLétavértes a significant number of thermal wells were drilled in the second half of the $2 \mathrm{O}^{\text {th }}$ century. Therefore, in the region of Létavértes only geologic studies, test drillings and calculations are available in relation to the local geothermal endowments, and in view of them the expected temperature of the water reaches $70^{\circ} \mathrm{C}$.

\section{Potential utilization of thermal water in the Létavértes-Săcueni region}

\section{Materials and methods}

In Kistelek of Csongrád County, 2002 saw the commencement of the planning works for a multiphase geothermal system utilizing thermal water. The $\mathrm{Mu}$ nicipality of Kistelek has implemented the nearly HUF 480 million project with the support of the Environmental Protection and Infrastructure Operational Programme (KIOP) and the own contribution fund of the Ministry of the Interior. The HUF 90 million own contribution of the local government needed for the investment has been covered from a bank loan to be repaid in 15 years, and at the same time the development is foreseen to return by the end of the tenor.

The basis of the geothermal public utility system is a 2095 -meter deep production well that supplies $82^{\circ} \mathrm{C}$ water at a rate of $90 \mathrm{cc} \mathrm{m} / \mathrm{h}$. The new district heating centers have been constructed by the existing facilities, and peak demands remain to be served with the use of gas (Olasz, 2007). To the public institutions, a network of heat-insulated lines of almost $6 \mathrm{~km}$ supplies the water. At the end of the heating cycle, the cooled water is returned to the 1678 -meter well situated at a distance of $2.5 \mathrm{~km}$ at a rate of $60 \mathrm{cc} \mathrm{m} / \mathrm{h}$ (Unk, 2007).

With the construction of the system, the operating costs of public institutions have decreased by $10 \%$ on the average. Furthermore, the emission of hazardous materials in the town has decreased. Carbon dioxide, carbon monoxide and nitrogen oxides show 1.38 kt p.a., $23.28 \mathrm{~kg}$ p.a. and $66.25 \mathrm{~kg}$ p.a. reductions. A particular result of the project is that the utilization of renewable energy resources has increased by 31.25 TJ p.a., which corresponds to a $0.1 \%$ rise (from $3.5 \%$ to 3.6\%) on a national scale (Olasz, 2007). Thus, nearly 1 million cc $m$ natural gas can be saved annually. To develop the system further, a thermal village is planned to be established in the surroundings of the reinjection well, while for the utilization of the $40^{\circ} \mathrm{C}$ thermal water before reinjection a display horticultural site is projected to generate an additional volume of $2 \mathrm{MW}$ heat output (Olasz, 2007). The utilization rate of the 
system could be further enhanced by installing heat pumps.

The analysis has started out from the following assumptions with partial reliance on the data of the geologic work team:

- The outlet temperature of the thermal water that can be exploited in Létavértes is $70-80^{\circ} \mathrm{C}$ (it depends on the drilling point in the Upper Pannonian water-bearing layer: expectedly $70^{\circ} \mathrm{C}$ in the north and $80^{\circ} \mathrm{C}$ in the south).

- The outlet temperature of the thermal water brought to the surface in Săcueni is $81^{\circ} \mathrm{C}$. No waters of higher temperature, such as in the range of $85^{-}$ $90^{\circ} \mathrm{C}$ have ever been exploited.
- According to the empiric data measured in Kistelek, the heat loss of the thermal water coming to the surface is $1^{\circ} \mathrm{C} / \mathrm{km}$ in the course of transportation.

- The available volume of the thermal water is sufficient to supply the central settlement and other locations potentially connected to the system.

On the basis of these data, as well as the linear and road distances among the municipal facilities to be supplied (in Létavértes, Săcueni), the production well and the settlements themselves, it can be determined in what an area and for what purposes the thermal water can be utilized, assuming that the central settlements are Létavértes and Săcueni. Table 2 shows the line-

Table 2. Linear and road distances of the settlements situated in the region of Létavértes-Săcueni from the central settlements (Source: based on data Google Maps and Google Earth)

\begin{tabular}{|c|c|c|c|c|}
\hline & Central settlement & Related settlements & Distance in bee line $(\mathrm{km})$ & Distance in road $(\mathrm{km})$ \\
\hline 1 & Létavértes & Kokad & 4.3 & 6.2 \\
\hline 2 & Létavértes & Álmosd & 8.1 & 9.2 \\
\hline 3 & Létavértes & Bagamér & 10.6 & 12.8 \\
\hline 4 & Létavértes & Újléta & 7.8 & 9.8 \\
\hline 5 & Létavértes & Hajdúbagos & 15.9 & 18.9 \\
\hline 6 & Létavértes & Monostorpályi & 7.5 & 9.6 \\
\hline 7 & Létavértes & Hosszúpályi & 10.7 & 12.7 \\
\hline 8 & Létavértes & Konyár & 17.2 & 27.9 \\
\hline 9 & Létavértes & Esztár & 14.3 & 17.8 \\
\hline 10 & Létavértes & Pocsaj & 13.2 & 15.0 \\
\hline 1 & Săcueni & Cubulcut & 6.8 & 10.2 \\
\hline 2 & Săcueni & Olosig & 4.7 & 6.2 \\
\hline 3 & Săcueni & Târguşor & 6.0 & 8.4 \\
\hline 4 & Săcueni & Adoni & 10.6 & 12.6 \\
\hline 5 & Săcueni & Cherechiu & 4.7 & 6.3 \\
\hline 6 & Săcueni & Cheşereu & 7.8 & 12.6 \\
\hline 7 & Săcueni & Şilindru & 11.7 & 39 \\
\hline 8 & Săcueni & Ciocaia & 3.7 & 7.6 \\
\hline 9 & Săcueni & Diosig & 9.2 & 12.2 \\
\hline 10 & Săcueni & Cadea & 5.0 & 5.9 \\
\hline 11 & Săcueni & Sânnicolau de Munte & 6.8 & 8.6 \\
\hline 12 & Săcueni & Létavértes & 17 & 18.2 \\
\hline 13 & Săcueni & Kokad & 12.9 & 19.1 \\
\hline 14 & Săcueni & Álmosd & 11.3 & 22.1 \\
\hline 15 & Săcueni & Bagamér & 13.1 & 25.7 \\
\hline 16 & Săcueni & Újléta & 20.5 & 27.4 \\
\hline 17 & Săcueni & Monostorpályi & 24.4 & 27.1 \\
\hline 18 & Săcueni & Hosszúpályi & 27.4 & 30.3 \\
\hline 19 & Săcueni & Konyár & 31.8 & 45.5 \\
\hline 20 & Săcueni & Esztár & 25.1 & 35.4 \\
\hline 21 & Săcueni & Pocsaj & 23.1 & 32.6 \\
\hline
\end{tabular}




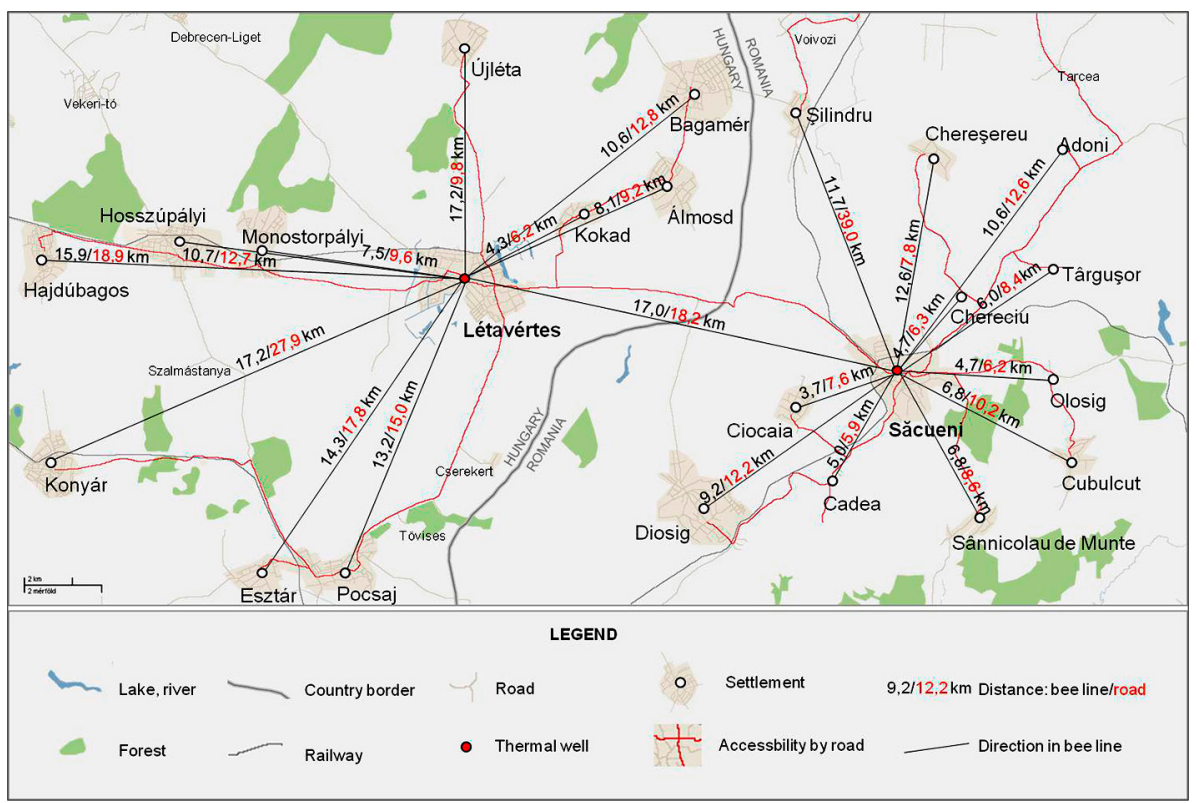

Figure 3. Settlements located in the Létavértes-Săcueni regio, that potentially connectable to the geothermal system (edited by the author based on Google maps)

ar and road distances to the surrounding settlements, while their actual locations are shown in Figure 3.

As depending on the temperature of the water, the potential areas of the utilization of thermal water are reflected in the Lindal diagram (Lindal, 1973). In the surroundings of Létavértes and Săcueni, the following potential areas of utilization can be identified:

- Bathing services, swimming pool: $30-50^{\circ} \mathrm{C}$

- Sanitary hot water: $50-70^{\circ} \mathrm{C}$

- Heating of greenhouses: $30-80^{\circ} \mathrm{C}$

- Heating of stables: $20-60^{\circ} \mathrm{C}$

- Heating of buildings with radiators: $70-100^{\circ} \mathrm{C}$

- Co-generation electric power plants: $80-170^{\circ} \mathrm{C}$

In view of the temperature of the water brought to the surface $\left(70-80^{\circ} \mathrm{C}\right)$, the establishment of co-generation electric power plants is not realistic, because the temperature of the water reaches the minimum value only in Săcuieni, and therefore this utilization option cannot be considered.

\section{Facilities that can be supplied with geothermal energy in the areas of Săcueni and Létavértes}

This section assesses those facilities - mostly serving public benefits or widely contributing to the satisfaction of communal demands -, and determines their locations whose operating costs and expenses can be considerably reduced with the utilization of geothermal energy. This category encompasses offices, educational institutions and elderly people's homes maintained by the local governments; bathing facilities strengthening tourist attractions; church institutions; areas of apartment blocks; industrial, commercial and agricultural facilities.

\section{Facilities suitable for the utilization of geothermal energy and their suppliability in Săcueni}

Săcueni functions as the administrative center of the territorial district forming Săcueni Territorial Unit of Public Administration (TUPA) with the surrounding five settlements. For better comparability with Létaverrtes, first only the suppliability of the facilities of Săcueni will be examined, followed by the suppliability of the associated settlements, as well as other settlements in the vicinity.

For the purpose of these studies, the thermal well established in the center of Săcueni has been selected to serve as the supply well, and thus I have measured the distances of the potential municipal consumers from this point. In the examination of suppliability, the linear and road distances of the public administration, educational and church institutions located within Săcueni, the parts of the town with commercial functions, areas of small-town buildup and tourism development features, as well as industrial and agricultural sites from the central thermal well have been measured.

According to the Lindal diagram, in the light of the water temperature ranges specified for the potential areas of utilization, the outlet temperature of the thermal water known from the empirical data of Săcueni and the distances of the prospective consumers from the well selected for the purpose of the studies it can be ascertained whether the given well - under the conditions described above - can supply all the facilities of the town with thermal water of appropriate temperature. The linear distance of the farthest consumer from the well is $3.6 \mathrm{~km}$, while on road it 
Table 3. Linear and road distances of the areas with various functions of Săcueni from the central thermal well (Source: based on data Google Maps and Google Earth)

\begin{tabular}{|l|l|l|c|c|}
\hline & Supply thermal well & Area is to be performed (in Săcueni) & $\begin{array}{c}\text { Distance in bee } \\
\text { line (km) }\end{array}$ & $\begin{array}{c}\text { Distance in road } \\
(\mathbf{k m})\end{array}$ \\
\hline 1 & Săcueni city central thermal well & Nordwest agricultural sites & 3.1 & 3.3 \\
\hline 2 & Săcueni city central thermal well & $\begin{array}{l}\text { Nordwest agricultural sites (Strada Letea } \\
\text { Mare) }\end{array}$ & 2.2 & 2.3 \\
\hline 3 & Săcueni city central thermal well & $\begin{array}{l}\text { Nord agricultural sites (Strada Avram } \\
\text { lancu) }\end{array}$ & 1.7 & 2.1 \\
\hline 4 & Săcueni city central thermal well & Southwest agricultural sites & 3.6 & 5.0 \\
\hline 5 & Săcueni city central thermal well & East agricultural sites & 3.6 & 3.8 \\
\hline 6 & Săcueni city central thermal well & Nord tourism development area & in $1.3 \mathrm{~km}$ & in $1.5 \mathrm{~km}$ \\
\hline 7 & Săcueni city central thermal well & Commercial zones & in $0.5 \mathrm{~km}$ & in $0.8 \mathrm{~km}$ \\
\hline 8 & Săcueni city central thermal well & Public institutions zones $0.5 \mathrm{~km}$ \\
\hline 9 & Săcueni city central thermal well & $\begin{array}{l}\text { Area of small town and area proposed for } \\
\text { conver-sion to small urban area }\end{array}$ & in $0.8 \mathrm{~km}$ & in $0.8 \mathrm{~km}$ \\
\hline 10 & Săcueni city central thermal well & Religious institutions & in $0.7 \mathrm{~km}$ & in $0.7 \mathrm{~km}$ \\
\hline 11 & Săcueni city central thermal well & $\begin{array}{l}\text { Utilized for industrial areas (Nordwest, } \\
\text { central) }\end{array}$ & 0.8 & in $1.0 \mathrm{~km}$ \\
\hline
\end{tabular}

LECEND

Area suppliable in $100 \%$

is $5.0 \mathrm{~km}$ away. Required for radiator-based heating with the largest heat demand, the minimum $70^{\circ} \mathrm{C}$ water can be ensured up to $10 \mathrm{~km}$ from the well located in the geographic center of the settlement. Therefore, the suppliability rate in Săcueni is $100 \%$ (Table 3; Figure 4).

\section{Facilities suitable for the utilization of geothermal energy and their suppliability in Létavértes}

For the studies performed in Létavértes, a theoretic thermal well has been used to examine the suppliability of the municipal facilities. The theoretical thermal well has been placed at the geographic center of the

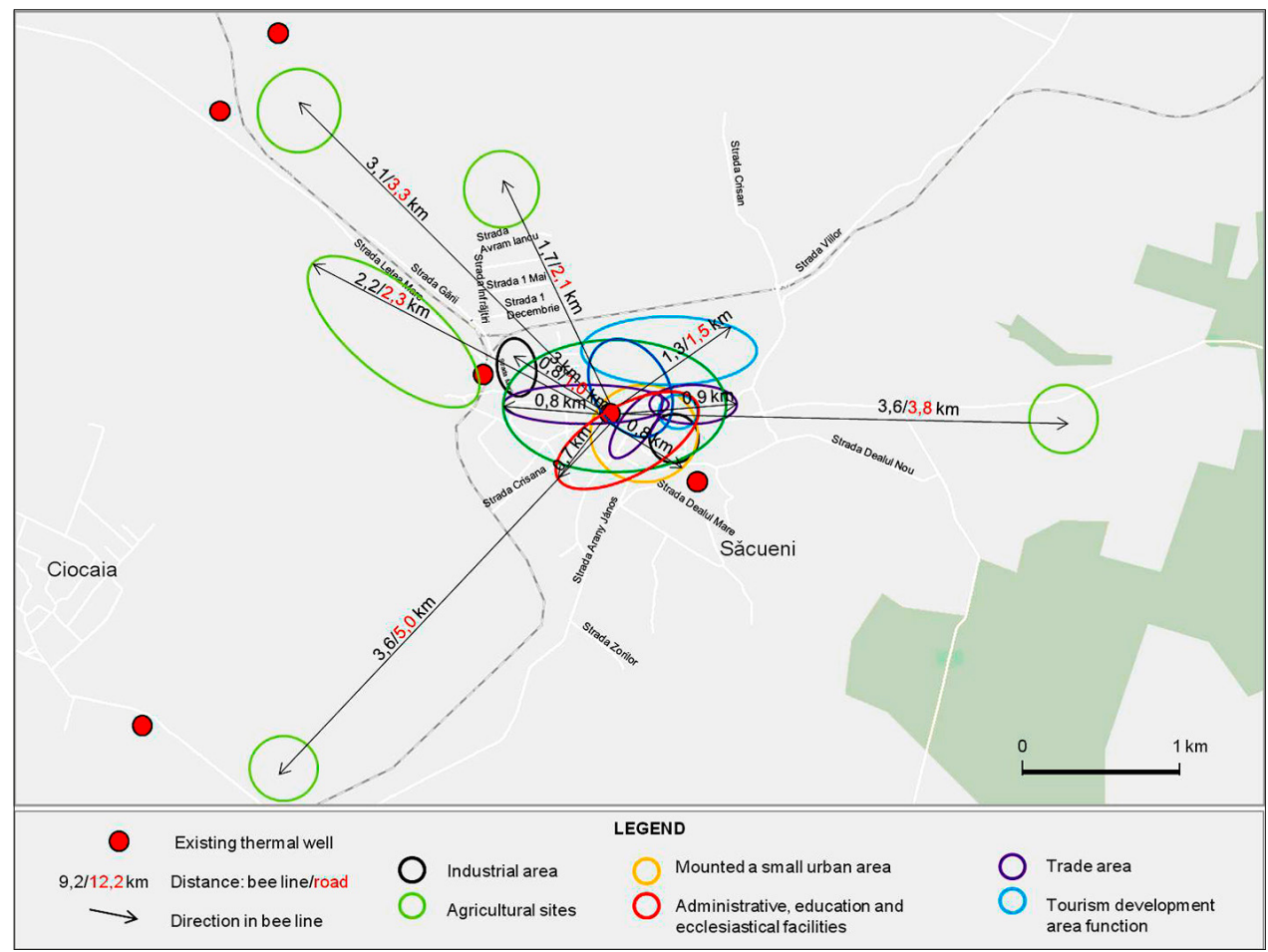

Figure 4. Potentials of geothermal energy supply of facilities in the Săcueni area from a thermal well in the center of town (edited by the author based on Google maps) 
Table 4. Linear and road distances of the areas with various functions of Létavértes from the central thermal well (Source: based on data Google Maps and Google Earth)

\begin{tabular}{|c|c|c|c|c|}
\hline & Supply thermal well & Area is to be performed (in Létavértes) & $\begin{array}{l}\text { Distance in } \\
\text { bee line }(\mathrm{km})\end{array}$ & $\begin{array}{l}\text { Distance in } \\
\text { road }(\mathrm{km})\end{array}$ \\
\hline 1 & Létavértes city central thermal well & Westhern, Kassai road (1.) agricultural sites & 3.3 & 4.1 \\
\hline 2 & Létavértes city central thermal well & Westhern, Kassai road (2.) agricultural sites & 2.9 & 3.4 \\
\hline 3 & Létavértes city central thermal well & Southern, Szélső str. (3.) agricultural sites & 2.6 & 3.7 \\
\hline 4 & Létavértes city central thermal well & Souteast, Nagyvárad str. (4.) agricultural sites & 2.5 & 2.8 \\
\hline 5 & Létavértes city central thermal well & Souteast, Nagyvárad str. (5.) agricultural sites & 3.5 & 4.8 \\
\hline 6 & Létavértes city central thermal well & East, Kossuth str. (6.) agricultural sites & 2.9 & 3.7 \\
\hline 7 & Létavértes city central thermal well & East, Kossuth str. (7.) agricultural sites & 2.6 & 4.5 \\
\hline 8 & Létavértes city central thermal well & Northern, Fenyő square (8.) agricultural sites & 1.4 & 2.0 \\
\hline 9 & Létavértes city central thermal well & Central (9.) agricultural sites & 0.1 & 0.1 \\
\hline 10 & Létavértes city central thermal well & $\begin{array}{l}\text { Souteast, Nagyvárad str. (10.) industrial land } \\
\text { for development }\end{array}$ & 2.5 & 2.8 \\
\hline 11 & Létavértes city central thermal well & Northern, Fenyő square (11.) industrial area & 1.0 & 1.5 \\
\hline 12 & Létavértes city central thermal well & Northwest, Szél str. (12.) industrial area & 2.2 & 2.4 \\
\hline 13 & Létavértes city central thermal well & $\begin{array}{l}\text { Administrative, educational and religious } \\
\text { facilities in Vértes quarter }\end{array}$ & 0.7 & 0.8 \\
\hline 14 & Létavértes city central thermal well & $\begin{array}{l}\text { Administrative, educational and religious } \\
\text { facilities in Újléta quarter }\end{array}$ & 1.5 & 1.7 \\
\hline 15 & Létavértes city central thermal well & Religious institution in Újléta southern & 2.1 & 2.3 \\
\hline 16 & Létavértes city central thermal well & $\begin{array}{l}\text { Small urbanized area for reconstruction in } \\
\text { Vértes city central }\end{array}$ & 1.2 & 1.3 \\
\hline 17 & Létavértes city central thermal well & $\begin{array}{l}\text { Small urbanized area for reconstruction in } \\
\text { Újléta city central }\end{array}$ & 1.8 & 1.9 \\
\hline 18 & Létavértes city central thermal well & Commercial zones in Újléta quarter & 2.3 & 2.5 \\
\hline 19 & Létavértes city central thermal well & $\begin{array}{l}\text { Tourism for development in the area in } \\
\text { Vértes and Újléta neighborhoods }\end{array}$ & 0 & 0 \\
\hline
\end{tabular}

LEGEND

Area suppliable in $100 \%$ Area suppliable in $80 \%$

town so that it could be the closest possible to the potential consumers. To define its parameters, the available geologic, geophysical and drilling research results have been used. Similarly to Săcueni, in the examination of suppliability the linear and road distances of the public administration, educational and church institutions located within Létavértes, the parts of the town with commercial functions, areas of small-town buildup and tourism development features, as well as industrial and agricultural sites from the central thermal well have been measured.

According to the Lindal diagram, in the light of the water temperature ranges specified for the potential areas of utilization, the outlet temperature of the thermal water known from the test drillings performed around Létavértes and the distances of the prospective consumers from the well created in theory for the purpose of the studies it can be ascertained whether the given well - under the conditions described above - can supply only those facilities of the town fully that lie within a range of $2.0 \mathrm{~km}$ from the well. To the consumers situated at any distance over $2.0 \mathrm{~km}$ from the well, the temperature of the thermal water needed for radiator-based heating cannot be ensured. Therefore, the suppliability rate in Létavértes is $88 \%$ (Table 4 ; Figure 5). 


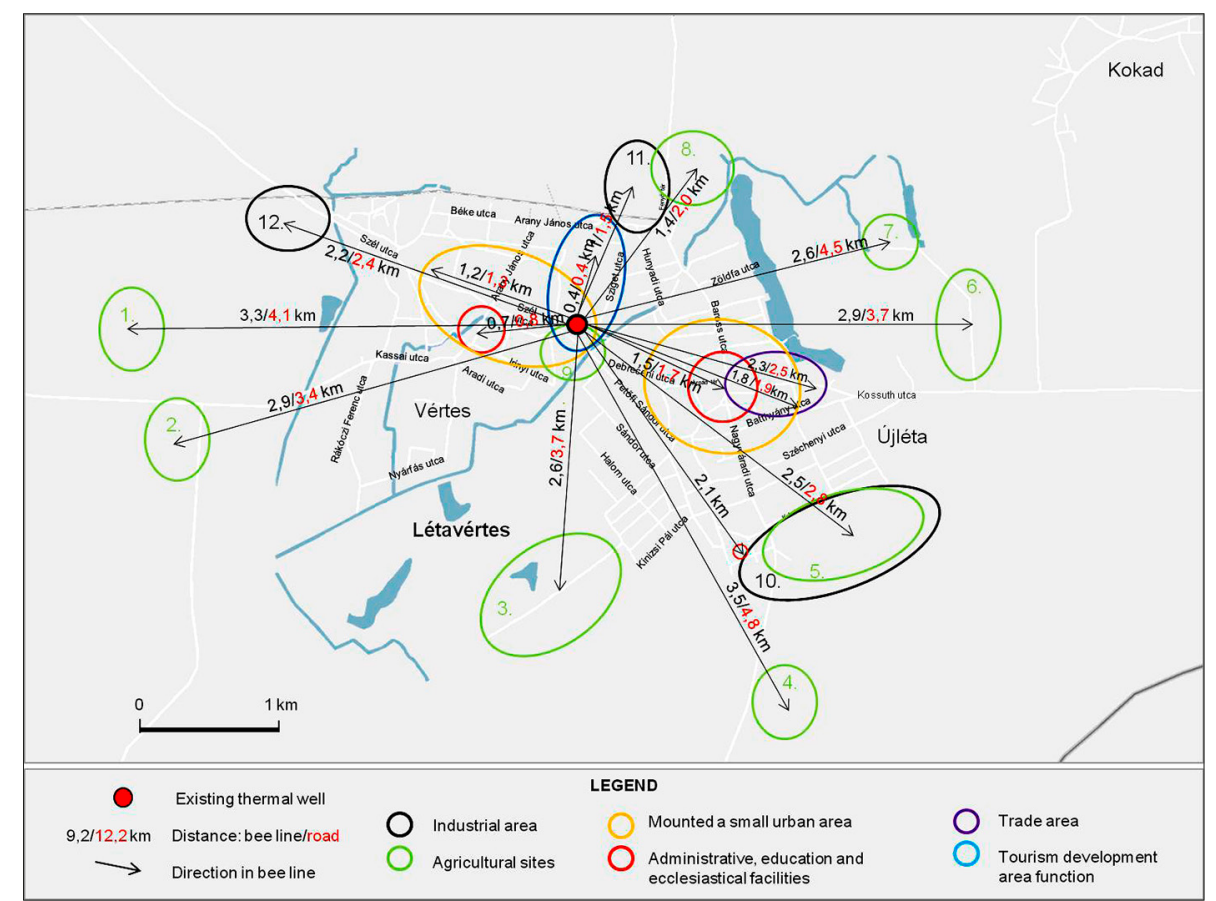

Figure 5. Potentials of geothermal energy supply of facilities in the Létavértes area from a theoretical thermal well in the center of town (edited by the author based on Google maps)

\section{Settlements where geothermal energy can be supplied in the surroundings of Săcueni and Létavértes}

Thereafter, it has been examined what percentage of the settlements lying in the local surroundings of the settlements of Săcueni and Létavértes - with the use of the above-mentioned thermal well parameters could be supplied with thermal water, and what demands could be satisfied with the thermal water of decreased temperature arriving at these settlements. In these studies, for both settlements only the surrounding areas within the territory of the parent country have been taken into account. The studies have assumed the availability of an ideal volume of thermal water. Both the linear and road distances of these settlements from Săcueni and Létavértes have been determined.

\section{Theoretical option to transport thermal water from the centers of Létavértes and Săcueni}

\section{Theoretical option to transport thermal water from the center of Létavertes}

In the light of the linear distances between Létavértes and the neighbouring Hungarian settlements as specified in Table 2 and the relevant water temperature data, Létavértes can supply all the neighbouring settlements with sanitary hot water, as well as thermal water of such temperature that is needed for swimming pools and bathing services, the heating of sta- bles and greenhouses. However, the temperature of the thermal water reaching the neighbouring settlements is too low to operated radiator-based heating. This latter service can be provided only in Létavértes - and even there to a limited extent (Table 5, Figure 6).

Table 5. Suppliability of the settlements in the surroundings of Létavértes, in linear distance, in a breakdown for the individual areas of utilization

\begin{tabular}{|l|c|}
\hline Area of utilization & $\begin{array}{c}\text { Relative suppliability, in } \\
\text { linear distance (\%) }\end{array}$ \\
\hline Radiator-based heating & 9 \\
\hline Sanitary hot water & 100 \\
\hline $\begin{array}{l}\text { Bathing services, swimming } \\
\text { pools }\end{array}$ & 100 \\
\hline Heating of stables & 100 \\
\hline Heating of greenhouses & 100 \\
\hline $\begin{array}{l}\text { Suppliability for all the } \\
\text { demands, on the average }\end{array}$ & 81 \\
\hline
\end{tabular}

In the light of the road distances between Létavértes and the neighbouring Hungarian settlements as specified in Table 2 and the relevant water temperature data, Létavértes can provide bathing and swimming pool services, as well as heat the stables and greenhouses in all the settlements concerned. With the exception of one settlement, Konyár, thermal water featuring temperature that is required for sanitary hot water services can be supplied to all the settlements, but for the radiator-based heating services 


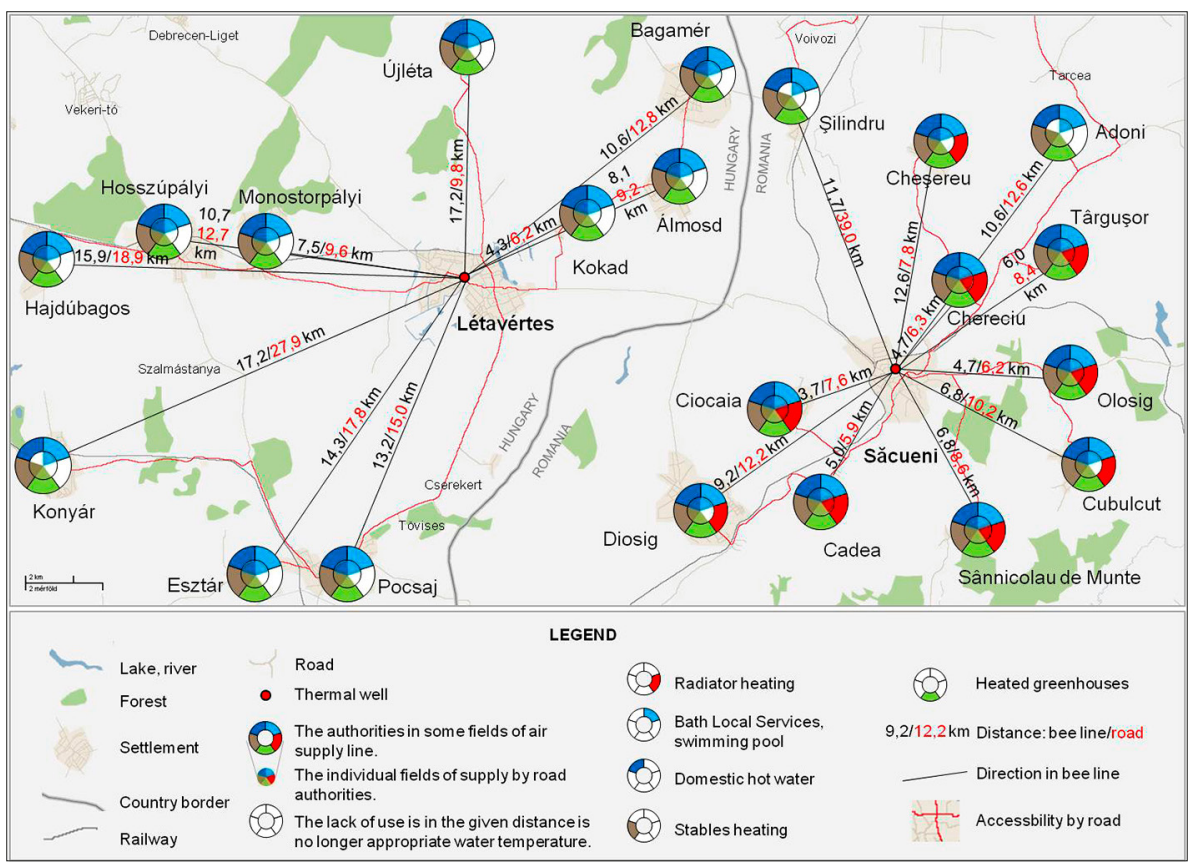

Figure 6. Supply options of the settlements in the Létavértes and Săcueni region in linear and road distances, in breakdown of areas of utilization (edited by the author based on Google maps)

the thermal water arrives at all the settlement with too low temperature (Table 6, Figure 6).

Table 6. Suppliability of the settlements in the surroundings of Létavértes, in road distance, in a breakdown for the individual areas of utilization

\begin{tabular}{|l|c|}
\hline Area of utilization & $\begin{array}{c}\text { Relative suppliability, in } \\
\text { road distance (\%) }\end{array}$ \\
\hline Radiator-based heating & 9 \\
\hline Sanitary hot water & 91 \\
\hline $\begin{array}{l}\text { Bathing services, swimming } \\
\text { pools }\end{array}$ & 100 \\
\hline Heating of stables & 100 \\
\hline Heating of greenhouses & 100 \\
\hline $\begin{array}{l}\text { Suppliability for all the } \\
\text { demands, on the average }\end{array}$ & 80 \\
\hline
\end{tabular}

\section{Theoretical option to transport thermal water from the} center of Săcueni

In the light of the linear distances between Săcueni and the neighbouring Romanian settlements as specified in Table 2 and the relevant water temperature data, Săcueni can supply all the neighbouring settlements with thermal water of such temperature that is needed for sanitary hot water, bathing services, the swimming pools, as well as the heating of stables and greenhouses. From among the neighbouring settlements, Silindru and Adoni lie at distances that the temperature of the thermal water transported to the two settlements is too low to operate radiator-based heating (Table 7, Figure 6).

Table 7. Suppliability of the settlements in the surroundings of Săcueni, in linear distance, in a breakdown for the individual areas of utilization

\begin{tabular}{|l|c|}
\hline Area of utilization & $\begin{array}{c}\text { Relative suppliability, in } \\
\text { linear distance (\%) }\end{array}$ \\
\hline Radiator-based heating & 83 \\
\hline Sanitary hot water & 100 \\
\hline $\begin{array}{l}\text { Bathing services, swimming } \\
\text { pools }\end{array}$ & 100 \\
\hline Heating of stables & 100 \\
\hline Heating of greenhouses & 100 \\
\hline $\begin{array}{l}\text { Suppliability for all the } \\
\text { demands, on the average }\end{array}$ & 96 \\
\hline
\end{tabular}

In the light of the road distances between Săcueni and the neighbouring Romanian settlements as specified in Table 2 and the relevant water temperature data, all the neighbouring settlements can be provided with bathing and swimming pool services, as well as heating for stables and greenhouses. For the radiator-based heating services, there are five settlements - Şilindru, Adoni, Chereşereu, Cubulcut and Diosig - that cannot be provided with appropriate temperature, while it is solely Şilindru where no sanitary hot water can be ensured. (Table 8, Figure 6). 
Table 8. Suppliability of the settlements in the surroundings of Săcueni, in road distance, in a breakdown for the individual areas of utilization

\begin{tabular}{|l|c|}
\hline Area of utilization & $\begin{array}{c}\text { Relative suppliability, in } \\
\text { road distance (\%) }\end{array}$ \\
\hline Radiator-based heating & 58 \\
\hline Sanitary hot water & 92 \\
\hline $\begin{array}{l}\text { Bathing services, swimming } \\
\text { pools }\end{array}$ & 100 \\
\hline Heating of stables & 100 \\
\hline Heating of greenhouses & 100 \\
\hline $\begin{array}{l}\text { Suppliability for all the } \\
\text { demands, on the average }\end{array}$ & 90 \\
\hline
\end{tabular}

\section{Theoretical option to transport thermal water only from the Săcueni center}

The transportability of thermal water has also been examined in a scenario where the neighbouring Romanian and Hungarian microregions are supplied from a single thermal well operated in the center of Săcueni, meaning that no thermal well should be established in Létavértes.

When the linear distances of the settlements are taken into consideration, the well located in Săcueni can supply water of appropriate temperature to all the settlements to ensure bathing and swimming pool services, as well as the heating of stables and greenhouses. For sanitary hot water services, however, the temperature of the water coming to the two farthest settlements - Konyár and Hajdúbagos - is not suffi- cient. Suppliability is even weaker for radiator-based heating, as there is not a single Hungarian settlement where such services can be rendered, and the same applies to Şilindru and Adoni on the Romanian side (Table 9, Figure 7).

Table 9. Suppliability of the settlements in the surroundings of Săcueni and Létavértes from Săcuieni, in linear distance, in a breakdown for the individual areas of utilization

\begin{tabular}{|l|c|}
\hline Area of utilization & $\begin{array}{c}\text { Relative suppliability, in } \\
\text { linear distance (\%) }\end{array}$ \\
\hline Radiator-based heating & 43 \\
\hline Sanitary hot water & 91 \\
\hline $\begin{array}{l}\text { Bathing services, swimming } \\
\text { pools }\end{array}$ & 100 \\
\hline Heating of stables & 100 \\
\hline Heating of greenhouses & 100 \\
\hline $\begin{array}{l}\text { Suppliability for all the } \\
\text { demands, on the average }\end{array}$ & 87 \\
\hline
\end{tabular}

When the road distances of the settlements are taken into consideration, the well in Săcueni can still ensure bathing and swimming pool services in all the settlements together with the heating of stables and greenhouses. With respect to sanitary hot water, suppliability cannot be realized in two other Hungarian settlements, Esztár and Pocsaj, and the temperature of the water would be similarly low in the Romanian settlement of Şilindru. Radiator-based heating can be ensured in none of the Hungarian settlements from the

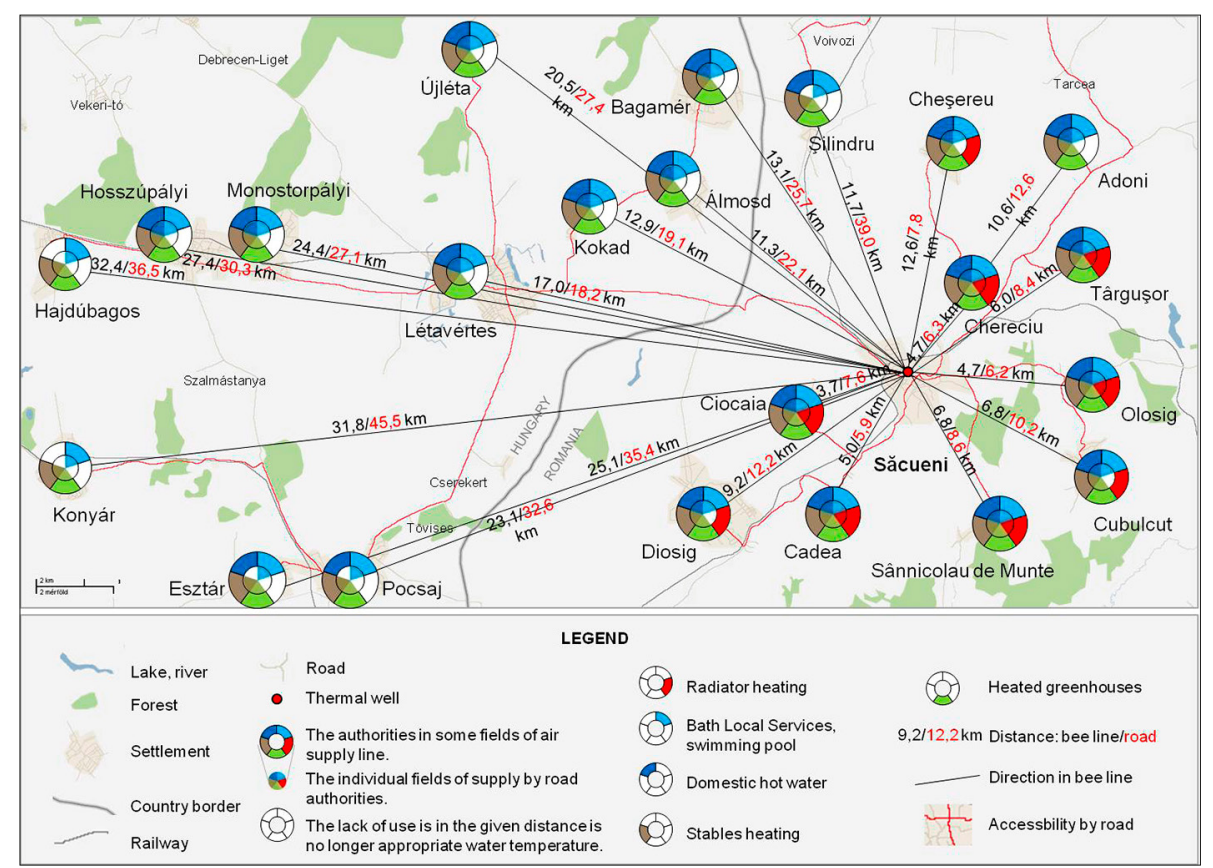

Figure 7. Supply options of the settlements in the Létavértes and Săcueni region only from Săcueni, in linear and road distances, in breakdown of areas of utilization (edited by the author based on Google maps) 
thermal water originating from Săcueni, as it arrives with to low temperature at the Romanian settlements of Şilindru, Adoni, Chereşereu, Cubulcut and Diosig (Table 10, Figure 7).

Table 10. Suppliability of the settlements in the surroundings of Săcueni and Létavértes from Săcuieni, in road distance, in a breakdown for the individual areas of utilization

\begin{tabular}{|l|c|}
\hline Area of utilization & $\begin{array}{c}\text { Relative suppliability, in } \\
\text { road distance (\%) }\end{array}$ \\
\hline Radiator-based heating & 30 \\
\hline Sanitary hot water & 78 \\
\hline $\begin{array}{l}\text { Bathing services, swimming } \\
\text { pools }\end{array}$ & 100 \\
\hline Heating of stables & 100 \\
\hline Heating of greenhouses & 100 \\
\hline $\begin{array}{l}\text { Suppliability for all the } \\
\text { demands, on the average }\end{array}$ & 82 \\
\hline
\end{tabular}

\section{Conclusion}

On the basis of the temperature of the thermal water, the heat loss during transportation, the thermal well and the facilities to be supplied in both Létavértes and Săcueni, as well as the linear and road distances of the settlements within the region from Létavértes and Săcueni, the following conclusions can be drawn:

The temperature of the thermal water that is theoretically available in Létavértes, and brought to the surface in Săcuieni allows the provision of water featuring appropriate temperature to the public administration, educational and church institutions located in the settlements, the parts of the towns with commercial functions, areas of small-town buildup and tourism development features, as well as industrial and agricultural sites. When transported to either the linear, or the road distance, the temperature of the water upon arrival at Létavértes and Săcuieni is sufficient for radiator-based heating, sanitary hot water supply, bathing and swimming pool services, and the heating of stables and greenhouses. The only exception is radiator-based heating in Létavértes, where water in temperature that is appropriate for servicing can be ensured only within a range of 2.0 kilometers.

When examining the supply of the settlements in the region of Létavértes and Săcueni, the thermal water brought to the surface in Săcueni has appropriate temperature for the heating of greenhouses and stables, and in this field even the farthest settlements can be supplied. The temperature of the thermal water that is theoretically available in Létavértes is also appropriate for the heating of agricultural facilities both with linear- and road-distance transport. It means that in theory agriculture can be served with geothermal energy.
From the center of Săcueni, the swimming pools and bathing facilities can be supplied with water, as well. It is obvious, however, that with swimming pool investments such additional costs would be incurred that do not allow the establishment of these facilities in every settlement. For larger settlements, primarily Létavértes, tourism investments based on thermal water can be regarded as realistic alternatives for boosting the local economy (Lindal, 1973).

Săcueni can deliver sanitary hot water to all the surrounding settlements on the Romanian side in linear distances, while in the Hungarian side settlements in any distance over $30 \mathrm{~km}$ from Săcueni such water supply is not feasible. These Hungarian settlements can be fully served only if the center of water supply is Létavértes. In road distances, Săcuieni cannot ensure appropriate temperature event to Şilindru on the Romanian side, and the same is true for Hajdúbagos, Konyár, Esztár and Pocsaj in Hungary. In case, the center of water supply is Létavértes, then only Konyár lies outside the $20 \mathrm{~km}$ range where the temperature of the arriving water tends to be too low.

For the radiator-based heating of residential buildings, even the $81^{\circ} \mathrm{C}$ water that is available in Săcueni is just restrictedly appropriate. In the Romanian side, such water supply of settlements lying farther than 10 $\mathrm{km}$ is not feasible, while in Hungary none of the settlements can be served. If Létavértes had $71^{\circ} \mathrm{C}$ thermal water, thermal water of sufficient temperature could be provided only to the central part of Létavértes. Within the settlement, linear and road distances are not significantly different from each other, and therefore with respect to the suppliability of radiatorbased heating the same facilities have been defined as suppliable and non-suppliable, respectively. If the temperature of the arriving water is determined with respect to the road distances, Săcueni is capable of ensuring the necessary temperature in none of the Hungarian settlements, and moreover four settlements on the Romanian side cannot be served either, as they are farther than $10 \mathrm{~km}$ on roads (Table 3-10; Figure 4-7).

The change of the political and economic system threw all the countries of Eastern and Central Europe into difficult situations. They were unprepared for the social and economic setup that they were unaccustomed to, and to which they have been able to adapt themselves just very slowly, with enormous sacrifices. To keep and enhance the competitiveness and attraction of a settlement, such a strategy should be framed that strives for exploiting the existing and attainable strengths, opportunities of the settlement to the utmost extent.

Létavértes and Săcueni want to grab all the locally available and attainable opportunities towards the well-balanced operation of the towns and the promo- 
tion of settlement development. One opportunity is the implementation of the investments that the settlements can finance and operate, as well as their gradual, scheduled expansion; on the other hand, the settlements can share their costs, and cooperate with each other in the field of energy supply. The burdens of such investments would be shouldered jointly, while the benefits are enjoyed by the stakeholders and population alike. This energy transfer cooperation can be interlocal, such as in the case of small towns lying on the two sides of the Hungarian-Romanian border.

\section{Acknowledgments}

This research was realized in the frames of TÁMOP 4.2.4.A/2-11-1-2012-00o1 „National Excellence Program - Elaborating and operating an inland student and researcher personal support system convergence program" The project was subsidized by the European Union and co-financed by the European Social Fund.

\section{References}

Bálint, A., Szongoth, G., 2010. Porózus közegbe történő visszasajtolás hatásának szimulációja teszt mérések alapján. Medencefejlődés és geológiai erőforrások, GeoLitera SZTE TTIK Földrajzi és Földtani Tanszékcsoport, Szeged, 23-25 pp.

Bohn, P., (föszerk.), Marczel, F-né., (szerk.). 1988. Magyarország mélyfúrási alapadatai. Retrospektív sorozat. 7. köt. Nagyalföld. 1883-1972. Budapest. 911, p. 57 térk.

Ciucanu, I., 2010. Chemical composition of the geothermal water in the north-western part of Romania. In: 16th „Building Services, Mechanical and Building Industry days" International Conference, 14-15 October, Debreceni Egyetem, Hungary, 23-24 pp.

Dövényi, P., Homola, V., Horváth, F., Kohl, T., Rybach, L., 2005. European HDR/EGS resources: Future potential development in Hungary. Order no: G109/05-22.13. - Final Report, GEOWATT AG (May 26), 1-41 pp.
Erdei, Z., Zsigmond, A. R., Szakács, S., 2010. Székelyhíd (Bihar megye, Románia) és környékén levő termálvizek vegyi jellemzése, XI. RODOSZ Konferencia, Kolozsvár, November 12-14., p. 9-14.

Gribovszki, Szeidovitz, 2002. A földrengés okozta talajmozgás és a talaj felerősítő hatásának modellezése két Debrecen városán keresztül húzódó szelvény mentén. Geomatikai Közlemények, MTA Geodéziai és Geofizikai Kutatóintézete, Sopron, 99-114.

Liebe, P., 2001. Tájékoztató. Termálvízkészleteink, hasznosításuk és védelmük. - Környezetvédelmi Minisztérium megbízásából készítette a VITUKI Rt. Hidrológiai Intézete, Budapest, 21 pp.

Lindal, B., 1973. Industrial and other applications of geothermal energy. In: Armstead, H.C.H., ed., Geothermal Energy, UNESCO, Paris, p.135-148.

Mádlné Szőnyi, J., 2008. A geotermikus energiahasznosítás nemzetközi és hazai helyzete, jövőbeni lehetőségei Magyarországon, Magyar Tudományos Akadémia, Budapest, 105 pp.

Molnár, B., 1984. A Föld és az élet fejlödése, Nemzeti Tankönyvkiadó, Szeged, 1984. 351 pp.

Olasz, J., (szerk.), 2007. Geotermikus energiahordozóra alapozott korszerü, környezetbarát távhőellátási rendszer Kistelek Város, Kistérségi Központ Intézményi hőenergia ellátására. AQUAPLUS Kft., Sándorfalva.

Popescu, V., 1981. Documentaţia asupra perimetrului Săcueni cu precădere asupra apelor geotermale şi resurse de hidrocarburi, Arh. Ministerului geologiei, Bucuresti.

Székelyhíd (Săcueni) Város, Bihar megye, Románia Fejlesztési Stratégiája, 2010. 77 pp.

Tóth, J., 2006. Az alföldi hévizek kettős eredete és annak gyakorlati következményei: egy megfigyelésekre alapozott hipotézis, Geotermia és Környezetipar a XXI. Században Szakkiállítás és Konferencia, Kistelek, január 30-31.

Unk, J.-né., 2007. A geotermikus energia hasznosítása Magyarországon, Csináljuk jól! Energiahatékonysági sorozat, Az Energia Központ Kht. kiadványa, Budapest 